\title{
THE ROLE OF RELATIONSHIP MARKETING AND SHARIAH COMPLIANCE ON CUSTOMERS' LOYALTY IN ISLAMIC MICROFINANCE
}

\author{
Anita Rahmawaty \\ State Islamic College (STAIN) Kudus \\ itarabma1275@gmail.com
}

\begin{abstract}
The purpose of this research is to examine and analize the effect of relationship marketing and shariah compliance on customers' satisfaction and loyalty. This research is a survey research which used a quantitative approach. The data were obtained from 185 respondents by using convenience sampling technique. The research model testing technique used the path analysis approach. The results showed that relationship marketing positively and significantly had effects on customers' satisfaction and loyalty. In this research, it is found also that shariah compliance is not related to customers' satisfaction. Nevertheless, it is found that shariah compliance is indirectly able to influence the loyalty through customers' satisfaction. Thus, the research findings suggest that relationship marketing becomes the important variable that affects the customers' satisfaction and loyalty.
\end{abstract}

Keywords: Relationship Marketing, Shariah Compliance, Customers' Satisfaction, Customers' Loyalty

\begin{abstract}
Abstrak
Tujuan penelitian ini adalah untuk menguji dan menganalisis pengarub relationship marketing dan shariah compliance terhadap kepuasan dan loyalitas nasabah. Penelitian inimerupakan jenispenelitian survey dengan menggunakan pendekatan kuantitatif. Data penelitian ini diperoleh dari 185 responden dengan menggunakan teknik convenience sampling. Teknikpengujian model penelitian ini menggunakan teknik analisis jalur (path analysis). Hasil penelitian ini menunjukkan bahwa relationship marketing berpengaruh secara positif signifikan terhadap kepuasan dan loyalitas nasabah. Dalam penelitian ini ditemukan pula bahwa shariah compliance tidak berpengarub secara signifikan terhadap kepuasan. Namun demikian, shariah compliance memiliki pengarub tidak langsung terhadap loyalitas melalui kepuasan nasabah. Dengan demikian, temuan penelitian ini menunjukkan bahwa relationship marketing merupakan variabel penting yang mempengarubi kepuasan dan loyalitas nasabah.
\end{abstract}

Kata Kunci: Relationship Marketing, Shariah Compliance, Kepuasan Nasabah, Loyalitas Nasabah.

Permalink/DOI: http://dx.doi.org/10.18326/infsl3.v10i1.1-24 


\section{Introduction}

The Islamic microfinance institutions (IMFIs) are important new sources for the development of micro institutions and while gaining support from the Islamic community. IMFIs are a grassroot establishment supported by funds from the Islamic community members. These IMFIs usually operate on the principle of profit-loss sharing, no interests paid and use the Islamic law and moral values and group solidarity as social capital to encourage repayment of loans (Rokhman, 2014: 4-5).

Nowadays, relationship marketing concept has been a key point of firm's business activities, especially IMFIs. Relationship marketing has emerged as a new paradigm in the marketing's concepts and practices. This paradigm has shifted from transactional approach to relationship based marketing strategy. The core of relationship marketing is relations among the company, suppliers, market intermediaries, and customers as the most important actor. This idea is to create customers' loyalty so that it can enhance stable, mutually profitable and long term relationship. Therefore, the long term orientation is a key of relationship marketing (Ravald and Gronroos, 1996: 19).

Relationship marketing is one leading new approach to marketing which eventually has entered the marketing literature (Gronroos, 1994: 4). It is recommended as a strategy to overcome service intangibility and appropriate for "credence" service. It is service that is difficult for customers to evaluate even after purchasing and using the products or service (Taleghani, et.al, 2011: 155). According to Gyasi (2012: 1; Taleghani, et.al, 2011: 156), relationship marketing focuses on developing, maintaining, enhancing and improving current customers, rather than attracting new customers. This business strategy assumes that consumers prefer to have an on-going relationship with one organization than to switch continually among providers in searching value.

Relationship marketing attempts to involve and integrate customers, suppliers and market intermediaries into a company's developmental and marketing activities (Sheth and Parvatiyar, 1995: 399). However, relationship marketing involves changing from the 
activities of acquiring customers to activities which concern having customers and keeping them (Mulindwa, 2005: 19). More companies have necessarily been committed to maintaining customers' loyalty and cultivating enduring relationships with customers. Therefore, marketers and managers are trying to obtain valuable information from the customers' needs to enhance long-term relationships with them to create the customers loyalty. According to Taleghani, et.al (2011: 155), this business strategy, apart from its ability to help understand customers' needs, can also create customers' loyalty and cost reduction.

The goal of relationship marketing is to improve and enhance marketing productivity by achieving efficiency and effectiveness (Sheth and Parvatiyar, 1995: 400; Mulindwa, 2005 :19). Alrubaiee and Al-Nazer (2010: 156) also consider relationship marketing to be the sustaining process of engaging in cooperative and collaborative activities. This strategy cultivates relationships with customers to enhance mutual economic value at reduced cost. Taleghani, et.al (2011: 156) explains that organizations seek benefits in order to maintain a relationship with their customers, so that they will be able to create a competitive advantage. It is also the same for the customers who seek a financial benefit to create relationship and improve their satisfaction and loyalty. So, the long-term relationship between an Islamic microfinance and its customers brings numerous financial benefits which have a real economic value. Some researchers have shown that the cost of serving one loyal customer is five to six times less than the cost of acquiring and serving one new customer.

Relationship marketing theory suggests that successful relationship marketing results from certain aspects of cooperative relationships. Alrubaiee and Al-Nazer (2010: 156) suggest that numerous factors which influence relationship marketing success, four factors consistently identified as important are bonding (Mulindwa, 2005: 12; Gyasi, 2012: 1; Taleghani, et.al, 2011: 155; Sucahyo, et.al, 2013: 151), trust (Morgan and Hunt, 1994: 20; Mulindwa, 2005: 12; Gyasi, 2012: 1; Taleghani, et.al, 2011: 155; Sucahyo, et.al, 2013: 151), commitment (Morgan and Hunt, 1994: 20; Mulindwa, 2005: 12; Taleghani, et.al, 2011: 155; Ndubisi, 2007: 98; Sucahyo, et.al, 2013: 151 ) and communication (Taleghani, et.al, 
2011: 155; Ndubisi, 2007: 98). Not just bonding, trust, commitment and communications; shared value, empathy and reciprocity have been also considered as important components of relationship marketing (Sin, et al., 2005: 185; Olotu, et.al, 2010: 47). Other studies indicate conflict handling as important component of relationship marketing (Ndubisi, 2007: 98; Taleghani, et.al, 2011: 155).

Several studies indicate that relationship marketing has positive impact on customers' loyalty (Alrubaiee \& Al-Nazer, 2010: 156; Ndubisi, 2007: 98; Taleghani, et.al, 2011: 155; Prabowo, 2008: 92; Sucahyo, et.al, 2013: 151; Semuel, 2012: 33). Other studies also indicates that relationship marketing has positive impact on customer retention (Gyasi, 2012: 1; Olotu, et.al, 2010: 47; Mulindwa, 2005: 12), but as mentioned above, the literature offers varied perspectives on which relational constructs mediate the effects of relationship marketing efforts on outcomes.

Customers' satisfaction is also supposed to be one of the most important criteria for customers' loyalty. A satisfied customer is supposed not to defect but to stay loyal to the firm for a long term and to buy more and more than the others (Ravald and Gronroos, 1996: 20). So customers' satisfaction is very important for any service industry, especially Islamic banking and finance. Customers' satisfaction can influence customers' loyalty and lead to profitability, market share and return on investment.

Prior studies also have shown that the shariah compliance has positive relationship to measure customer services quality in Islamic Banking Industry (Othman and Owen, 2001: 1). However, the satisfaction and customers' loyalty, additional constructs are required to be integrated to affect the loyalty of Islamic microfinance customers. In this study, shariah compliance is proposed to enhance the understanding of customers' satisfaction and loyalty in Islamic microfinance.

For this reason, the main objective of this paper is to investigate the effect of relationship marketing and shariah compliance empirically on customers' loyalty of Islamic microfinance customers. This study focused on two factors. They were relationship marketing and shariah compliance that influence on customers' satisfaction and loyalty. 


\section{Relationship Marketing}

The concept of relationship marketing has emerged within the field of services marketing and industrial marketing (Gronroos, 1994: 9, Taleghani, et.al, 2011: 156, Ndubisi, 2007: 99) and developed in the late of 1980 and 1990s (Taleghani, et.al, 2011: 156). Relationship marketing emerged in the 1980s as an alternative to the prevailing view of marketing as a series of transactions, because many exchanges, particularly in the service industry, were relational by nature. Today, the concept of relationship marketing is strongly supported by on-going trends in modern business (Gronroos, 1994: 9; Taleghani, et.al, 2011: 156).

The conception and growth of relationship marketing has development steps: (1) Pre-Industrial era when direct marketing was the order of the day, (2) The Industrial era which refers to the period of industrial revolution that gives rise to mass production and mass consumption of goods and services, and (3) The PostIndustrial era which witnessed a change in marketing practices from transactional approach to relationship based marketing strategy.

Table 1 revealed the transition of marketing theory from preindustrial era to post-industrial era. And, this paradigm shift has changed the basic foundations of marketing which was buried in theory exchange (Olotu, et.al, 2010: 48).

Table 1.

The Pre-industrial, Industrial and Post-industrial eras of Marketing

\begin{tabular}{|cccc|}
\hline Period & Pre-Industrial & Industrial Era & Post-Industrial \\
& Era & & Era \\
Orientation & Direct & Transactional & Relationship \\
& Marketing & Marketing & Marketing \\
\hline
\end{tabular}

Source: Olotu, et.al (2010: 48) 
In 1983, the term "relationship marketing" was first introduced by Berry in a service context to describe a longer-term approach to marketing. Berry viewed that relationship marketing as a strategy to attract, maintain and enhance customer relationships (Ndubisi, 2007: 99; Sin, et.al, 2005: 186; Taleghani, et.al, 2011: 156). According to Gronroos (1994: 9), the purpose of relationship marketing is to establish, maintain and enhance relationships with customers and other parties to get a profit so that the objectives of all parties are fulfilled. And, this is done by mutual exchange and fulfillment of promises. Similarly, Rapp and Collins in Gronroos (1994: 19; Ndubisi, 2007: 99) explain that the purpose of relationship marketing is to create and maintain ending relationships between the company and its customers that are rewarding for both sides. Recently, Harker in Sin. et.al (2005: 186) proposed to add "proactively creating, developing and maintaining" to the definition. The above definitions focus on individual buyer-seller relationships that are in long term and mutually beneficial. In short, the relationship marketing concept can be viewed as a paradigm of business successfully, or as a distinct organizational value that maintains the buyer-seller relationship as the center of the company's business strategy.

Palmatier (2008: 3) defines that relationship marketing is the process of identifying, developing, maintaining, and terminating relational exchanges with the goal of enhancing performance. In other word, Alrubaiee and Al-Nazer (2010: 157) stated that relationship marketing describes all marketing activities which are directed toward establishing, developing, and maintaining successful relationship exchanges. So that, relationship marketing theory suggests that successful relationship marketing is from certain aspects of cooperative relationships that characterize successful relational exchanges.

The American Marketing Association's (AMA) defines: "Relationship marketing is a kind of marketing that its purpose is developing, maintaining, enhancing and managing long-term and trustworthy relationships with customers, suppliers and all of other actions in the market" (Taleghani, et.al, 2011: 156). There are four basic values for relationship marketing. First, the activities regarding relationship marketing do not focus upon a specialized 
department, but there must be a marketing orientation of the whole company. Second, relationship marketing emphasizes on long-term collaboration, so firms should view their suppliers and customers as partners, where the purpose is to enhance mutual value. The relationship must be meaningful for all those who are involved, with the goal of enhancing long-term relationships with parties. Third, all parties should accept responsibilities. Relationship must also be interactive, so customer can initiate development, improvement or innovation of the product or service. Fourth, customers should be considered as individuals, suppliers' task is also to make value for the customers (Taleghani, et.al, 2011: 156).

Therefore, Gummesson in Gronroos (1994: 19) concludes that relationship marketing is a business strategy where the management of interactions, relationships and networks are as the key of marketing. This is achieved by mutual symbiosis and fulfillment of promises (Ndubisi, 2007: 99). Consequently, customer relationships are at the center of this marketing perspective. Relationship marketing adopts a customer focus and its main benefits include greater customer retention, increased loyalty, reduced marketing costs, and greater profits and the purpose of relationship marketing is to form mutually beneficial alliances by creating barriers to entry (Taleghani, et.al, 2011: 157). Similarly, Christopher et al. in Gronroos (1994: 19) also consider relationship marketing is a strategy that aligns marketing, customer service and quality, with an emphasis on a focus on customer retention, an orientation on product or service benefit, a long time scale, a high customer service orientation, a high customer commitment and a high customer contact as well as on the opinion that quality is the concern of all.

Kotler and Armstrong's definition of relationship marketing is creating, maintaining and enhancing strong relationships with customers and other stakeholders. It is oriented to the long-term. And, the purpose of relationship marketing is to deliver longterm value for customers, and the measure of success is long-term customers' satisfaction (Taleghani, et.al, 2011: 157). In other words, the key of relationship marketing objective is to enhance customers' loyalty, which Oliver in Ndubisi (2007: 99) defined as a highly deep commitment to re-patronize a preferred product or service in the 
future despite there are situational influence and marketing efforts having the potential to create switching behavior. It is a feasible manner for Islamic microfinance to establish a unique long-term relationship with their customers.

Nevertheless, Reichheld in Gronroos (1994: 10) observed that developing the customers' loyalty cannot be done simply. It must be integrated with the firm's basic business strategy. Hence, it should be meaningful to think about possible marketing strategies in a marketing strategy continuum. Relationship marketing is placed at one end of the continuum and the general focus is on building relationships with customers. The continuum is transaction marketing where the focus of marketing is on one transaction at a time. Thus marketing revolves developing single transactions and not building long-term relationships.

The continuum and some marketing and management implications are illustrated in table 2 .

Table 2.

The Marketing Strategy Continuum: Some Implications

\begin{tabular}{|c|c|c|}
\hline $\begin{array}{l}\text { The Strategy } \\
\text { Continuum }\end{array}$ & Transaction Marketing & $\begin{array}{l}\text { Relationship } \\
\text { Marketing }\end{array}$ \\
\hline Time Perspective & Short-term focus & Long-term focus \\
\hline $\begin{array}{l}\text { Dominating } \\
\text { marketing Function }\end{array}$ & Marketing Mix & $\begin{array}{l}\text { Interactive Marketing } \\
\text { (supported by } \\
\text { marketing-mix } \\
\text { activities) }\end{array}$ \\
\hline Price elasticity & $\begin{array}{l}\text { Customer tend to } \\
\text { be more sensitive to } \\
\text { price }\end{array}$ & $\begin{array}{l}\text { Customer tend to be } \\
\text { less sensitive to price }\end{array}$ \\
\hline $\begin{array}{l}\text { Dominating quality } \\
\text { dimension }\end{array}$ & Quality of output & Quality of interactions \\
\hline $\begin{array}{l}\text { Measurement of } \\
\text { customers' satisfaction }\end{array}$ & $\begin{array}{l}\text { Monitoring market } \\
\text { share }\end{array}$ & $\begin{array}{l}\text { Managing the } \\
\text { customer base }\end{array}$ \\
\hline
\end{tabular}




\begin{tabular}{|c|c|c|}
\hline $\begin{array}{l}\text { Customer information } \\
\text { system }\end{array}$ & $\begin{array}{l}\text { Ad hoc customers' } \\
\text { satisfaction surveys }\end{array}$ & $\begin{array}{l}\text { Real-time customer } \\
\text { feed-back system }\end{array}$ \\
\hline $\begin{array}{l}\text { Interdependency } \\
\text { between marketing, } \\
\text { operations, and } \\
\text { personnel }\end{array}$ & $\begin{array}{l}\text { Interface of no or } \\
\text { limited strategic } \\
\text { importance }\end{array}$ & $\begin{array}{l}\text { Interface of } \\
\text { substantial strategic } \\
\text { importance }\end{array}$ \\
\hline $\begin{array}{l}\text { The role of internal } \\
\text { marketing }\end{array}$ & $\begin{array}{l}\text { Internal marketing } \\
\text { of no or limited } \\
\text { importance to success }\end{array}$ & $\begin{array}{l}\text { Internal marketing of } \\
\text { substantial strategic to } \\
\text { success }\end{array}$ \\
\hline
\end{tabular}

\section{Source: Gronroos (1994: 11)}

Some marketing literature theorized key dimensions in relationship marketing. This new concept of marketing is a multidimensional construct, with strong correlations that are positively associated with bank performance (Olotu, et.al, 2010: 49; Sin et.al, 2005: 187). Sin et al (2005: 187; Olotu, et.al, 2010: 49) stated that there are six dimensions of relationship marketing. They are: trust, bonding, communication, shared value, empathy, and reciprocity. These identified variables are directly linked to and are capable to predict customers' loyalty. According to Alrubaiee and Al-Nazer (2010: 155), relationship marketing as a multi-dimensional constructs five behavioral components: trust, commitment, communications, bonding and satisfaction. Results of regression analysis show that relationship marketing is significant in explaining the variation of customers' loyalty. Taleghani, et.al (2011: 161) provides empirical evidence for the influence of customers' loyalty related to eight underpinnings of relationship marketing: trust, commitment, communication, conflict handling, bonding, shared values, empathy and reciprocity. This research adds value to the literature which empirically investigates the impact of relationship marketing underpinnings on customers' loyalty in the Islamic banking and finance industry.

Scholars have listed some key virtues that have been theorized in the relationship marketing literature, for example, trust (Morgan and Hunt, 1994: 20; Sin, et.al, 2005: 185; Ndubisi, 2007: 98, Alrubaiee and Al-Nazer, 2010: 156; Mulindwa, 2005: 12; 
Gyasi, 2012: 1; Taleghani, et.al, 2011: 155; Sucahyo, et.al, 2013: 151), commitment (Morgan and Hunt, 1994: 20), empathy (Ndubisi, 2007: 98, Taleghani, et.al, 2011: 155), conflict handling (Ndubisi, 2007: 98; Taleghani, et.al, 2011: 155), and communication (Morgan and Hunt, 1994: 20; Ndubisi, 2007: 98; Taleghani, et.al, 2011: 155, Alrubaiee and Al-Nazer, 2010: 156). Other scholars (e.g., Morgan and Hunt, 1994: 20; Sin et al, 2005: 185; Taleghani, et.al, 2011: 155, Alrubaiee and Al-Nazer, 2010: 156, Olotu, et.al, 2010: 47) have documented the constructs, namely, shared values, bonding, and reciprocity as the underpinnings of relationship marketing.

Based on the literature, we hypothesized that relationship marketing was one dimensional construct consisting five underpinnings (namely bonding, communication, commitment, conflict handling, trust) and in this research, they have been linked to the customers' loyalty. Taleghani, et.al, (2011: 157) has suggested that firms should make sacrifices and worthwhile investments in building relationships loyally, or at least potentially loyal. It is argued that the five identified underpinnings of relationship marketing are directly linked to and are capable of predicting customers' satisfaction and loyalty.

\section{Shariah Compliance}

The concept of shariah compliance was formally introduced by Othman and Owen (2001: 3), who defined it, as "the ability to fulfill with Islamic Law and operate under the basic principles of Islamic banking and economy". Othman and Owen (2001: 3) conceptualized the CARTER model for measuring quality of services in Islamic banks and the findings showed that the shariah compliance is important for the banks to adopt service quality program.

The CARTER model is an instrument that might be used to develop and measure Islamic banking service quality and to create meaningful quality-assessment tools. In addition, it includes the compliance of Islamic law and basic principles of all SERVQUAL five dimensions. The CARTER model may finally enhance the benefits to the Islamic banks and Islamic micro finances: (1) It is 
the first strategy to add and mix the customers' religious beliefs and cultural values with other quality dimensions; (2) It provides multifaced analysis of customers' satisfaction; (3) It links quality with customers' satisfaction; (4) It provides information at several levels, already organized into meaningful groupings; (5) It is a business strategy, which results in usable answers to meet customers' needs (Othman and Owen, 2011: 3).

Othman and Owen (2001: 6) conceptualize shariah compliance with some indicators. They are running on Islamic law and basic principles, no interest neither paid nor taken on savings and loans, provision of Islamic products and services, provision of free interest loans and provision of profit-sharing investment products.

Muslims are prohibited by their religion to deal with the interest (riba). Thus, an Islamic banking and Islamic finance system cannot pay any interest to those who save or deposit their money, nor may they collect from those who borrow money from them. The lender is expected to return his or her capital fully without any interest. In general, all interest-free banks agree on the same principles (Othman and Owen, 2001: 1).

Based on the literature, we hypothesized that shariah compliance is a construct and they have been measured and linked in this study to customers' satisfaction and loyalty. It is argued that the shariah compliance is directly linked to and is capable of predicting customers' satisfaction and loyalty.

\section{Customers' Satisfaction}

Customers' satisfaction is a psychological concept that involves the feeling of pleasure from obtaining needs and expectations. It is however not universal phenomena. It means that not everyone gets the same satisfaction because they have the different experience although it is in same industry. It can be concluded that different customers could have different needs, objectives and experiences that influence their expectations (Mulindwa, 2005: 25).

Customers' satisfaction is a complex construct and has been defined in various ways. Oliver (1997: 13) defined satisfaction as the 
customers' evaluative judgment related to a product or service feature providing a pleasurable level of consumption-related fulfillment. Zeithaml and Bitner in El-Refae (2012: 199) explain that satisfaction is the customer's evaluation of a product or service in terms of whether that product or service has met their needs and expectations.

Satisfaction refers to the buyer's statement of being adequately rewarded in buying situation for his sacrifice (El-Refae, 2012: 199). Howard and Sheth in Tuan (2012: 133) defined customers' satisfaction as a psychological statement to evaluate the reason between what a customer actually pays and gets. Churchill and Surprenant in Tuan (2012: 133) proposed that customers' satisfaction derived from the comparison between expected reward and actual cost of buying. Hanzaee and Khanzadeh (2011: 567) also stated that customers' satisfaction as the degree of overall pleasure felt by the customer, resulting from the ability of the service provider to fulfill the customers' needs and expectations.

According to Tuan (2012: 134), customers' satisfaction is the key to a company's success and long-term competitiveness. Mulindwa (2005: 26) describes that the most important relationship marketing is relationship with the customer and the goal is satisfied customer, productive and enduring relationship. So the fundamental principle of relationship marketing is that company can enhance customers' satisfaction through a relationship and enhancing their own performance.

Ravald and Gronroos (1996: 19) suggest that the success of a relationship is a mutually profitable relationship for suppliers and buyers depends on the ability to provide value by increasing the benefits and or reducing the sacrifice for the customer. Thus, it will improve satisfaction and stimulate repurchase. According to Mulindwa (2005: 26), key of relationship marketing would involve responding to customers' needs and requirements quickly and developing new products or services by anticipating future customer expectations.

The relationship between relationship marketing and customers' satisfaction has also been studied in inter-organizational relationships, where researchers acknowledged that relationships 
will lead to assessment of economic efficiency, fairness of past transaction and lead to supplier's satisfaction. Satisfied customers create a strong relationship with the provider and this leads to customers' loyalty and by adding revenues over time, customer relationship profitability is improved (Mulindwa, 2005: 26). Therefore, customers' satisfaction is supposed to be one of the most important criteria for customers' loyalty.

\section{Customers' Loyalty}

It is important that the main purpose of customer oriented behaviors is to increase customers' satisfaction and to create customers' loyalty. It means that the main theme in customer relationship marketing is to get and keep the loyalty of customers (Alrubaiee and Al-Nazer (2010: 157). Therefore, the Islamic microfinance institutions (IMFIs), as the micro-finance institutions, can retain profitable customers and increase their loyalty by planning their marketing strategies.

Rizan, et.al (2014: 3) stated that customers' loyalty was an intention to get and keep a valuable relationship. Ndubisi (2007: 2) defined customers' loyalty as a highly deep commitment to repatronize a preferred product or service in the future regardless of the fact that there are situational influence and marketing efforts having the potency to create switching behavior. In the Islamic microfinance sector, the main job of manager and marketers is to create, develop and enhance customers' loyalty if they want to maintain their firms and increase its profitability. Alrubaiee and Al-Nazer (2010: 157) also thinks that loyalty is the function of satisfaction, switching barriers and voice. Loyal customers may not be always satisfied, but satisfied customers must be loyal customers.

Based on the above discussion, the following hypotheses are proposed:

$\mathrm{H}_{1}$ : Relationship marketing has a direct positive effect on customers' satisfaction.

$\mathrm{H}_{2}$ : Shariah compliance has a direct positive effect on customers' satisfaction. 
$\mathrm{H}_{3}$ : Relationship marketing has a direct positive effect on customers' loyalty.

$\mathrm{H}_{4:}$ Shariah compliance has a direct positive effect on customers' loyalty.

$\mathrm{H}_{5:}$ Customers' satisfaction has a direct positive effect on customers' loyalty.

Figure 1 illustrates the research model that summarizes the constructs and hypothesis developed by this study.

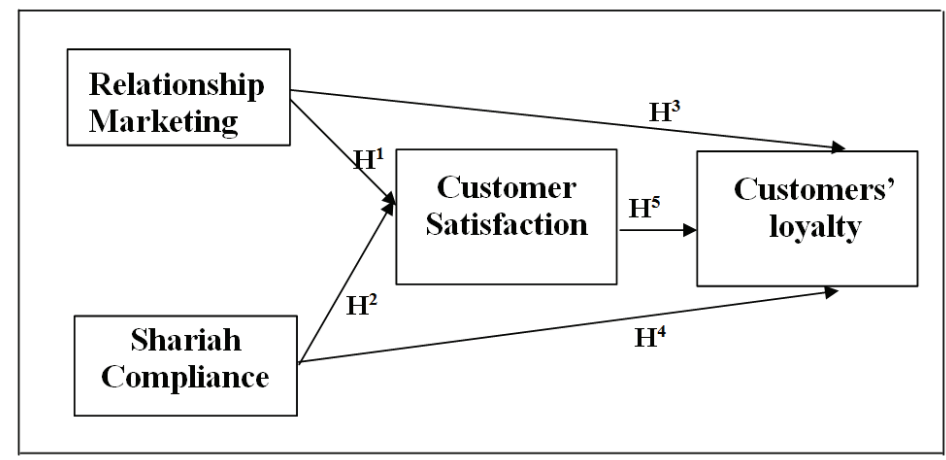

Figure 1.

Research Model

\section{Research Method}

\section{Population, Sample and Instrument}

This research was conducted to examine the effect of relationship marketing and shariah compliance on customers' satisfaction and customers' loyalty. The population was 200 and the questionnaires were distributed among the customers of Islamic microfinance Demak, Central Java, Indonesia, and using stratified random sampling method. From 200 distributed questionnaires, the researchers received back 185 responses. The questionnaires were related to the effect of relationship marketing, shariah compliance, customers' satisfaction and customers' loyalty.

This study selected the measurement items which had reliability and validities. They had been verified from previous studies; some are modified to align with this study. The items and 
related literatures are listed in Table 3. The final questionnaire consisted of 27 items, not including some general questions, such as name, gender, age, education level, profession and time period being customers in Islamic microfinance. All items were measured by using 5 point likert scale (ranging from ' 1 '= strongly disagree to ' 5 '= strongly agree).

Table 3.

Questionnaire Items and References

\begin{tabular}{|c|c|c|c|}
\hline No & Research Variables & Items & Reference \\
\hline 1 & Relationship Marketing & 15 & $\begin{array}{l}\text { Sin, et.al (2005) } \\
\text { Alrubaiee and Al-Nazer (2010) } \\
\text { Semuel (2012) } \\
\text { Ndubisi (2007) }\end{array}$ \\
\hline 2 & Shariah Compliance & 4 & Othman and Owen (2001) \\
\hline 3 & Customers' satisfaction & 4 & Alrubaiee and Al-Nazer (2010) \\
\hline 4 & Customers' loyalty & 4 & $\begin{array}{l}\text { Rizan, et.al (2014) } \\
\text { Semuel (2012) }\end{array}$ \\
\hline
\end{tabular}

The Analysis Method

To test the proposed hypotheses, this study used a path analysis approach. Path analysis provides researchers to model the relationships among multiple independent and dependent constructs simultaneously in a single, systematic, and comprehensive analysis. In this research, the principal software Amos 16.0 is utilized for the measurement (Ghozali, 2008: 21).

\section{Results and Analysis}

\section{Sample Characteristic}

The demographic characteristics of the sample were shown in Table 4. 
Table 4.

The Characteristics of Respondents

\begin{tabular}{|c|c|c|}
\hline Demographic Variables & Frequency & Percentage \\
\hline \multicolumn{3}{|l|}{ Gender } \\
\hline - Male & 95 & 51 \\
\hline - Female & 90 & 49 \\
\hline \multicolumn{3}{|l|}{ Age } \\
\hline - Less than 25 & 35 & 19 \\
\hline - $\quad 26-30$ & 20 & 11 \\
\hline - $\quad 31-35$ & 69 & 37 \\
\hline - $\quad 36-40$ & 26 & 14 \\
\hline - 41 - above & 35 & 19 \\
\hline \multicolumn{3}{|l|}{ Education Level } \\
\hline - $\quad$ Primary & 17 & 9 \\
\hline - Secondary & 17 & 9 \\
\hline - Post Secondary & 67 & 36 \\
\hline - Graduate (S1) & 72 & 42.5 \\
\hline - Post Graduate (S2) & 6 & 3.5 \\
\hline \multicolumn{3}{|l|}{ Profession } \\
\hline - Entrepreneurs & 80 & 43 \\
\hline - Teacher & 45 & 24 \\
\hline - Worker & 15 & 8 \\
\hline - Farmer & 10 & 6 \\
\hline - $\quad$ Students & 35 & 19 \\
\hline \multicolumn{3}{|c|}{ Time period in Islamic Microfinance } \\
\hline (year) & 20 & 11 \\
\hline - Less than 1 & 45 & 24 \\
\hline - $\quad 1-2$ & 48 & 26 \\
\hline - $3-4$ & 72 & 39 \\
\hline \multicolumn{3}{|l|}{ - $\quad$ More than 4} \\
\hline Total & 185 & 100 \\
\hline
\end{tabular}

From the above table, the respondents characteristics are about fifty one percent (51\%) of the respondents are male, approximately 69 of total 185 respondents (37\%) range in age 31- 35 years old. With regards to educational background as shown in table above, $9 \%$ was primary and secondary level, 38\% was post secondary level, and $42.5 \%$ forming the larger group was graduate and $3.5 \%$ at post 
graduate level. For profession, the majority type of respondents (43\%) was entrepreneur, teacher forming the second largest group was $24 \%$ and the rest were workers, farmers and students. Regarding time period in Islamic microfinance, the majority of respondents (39\%) were already in Islamic microfinance more than 4 years.

The following table 5 displays the means, standard deviation, standard error mean and correlation for four variables, namely the relationship marketing, shariah compliance, customers' satisfaction and customers' loyalty.

Table 5.

Mean, Standard Deviation and Correlation

\begin{tabular}{llccllll}
\hline No & Variable & Mean & S.D & RM & SC & ST & LY \\
\hline 1 & Relationship Marketing & 4.1 & .27 & 1 & & & \\
2 & Shariah Compliance & 3.8 & .48 & 332 & 1 & & \\
3 & Customers' satisfaction & 4.0 & .39 & 501 & 116 & 1 & \\
4 & Customers' loyalty & 4.0 & .42 & 414 & 267 & 322 & 1 \\
\hline
\end{tabular}

\section{Path Analysis Model Results}

The path analysis model suggested in this study was tested using the maximum likelihood method with AMOS 16.0. Overall results are summarized in figure 2 and table 6.

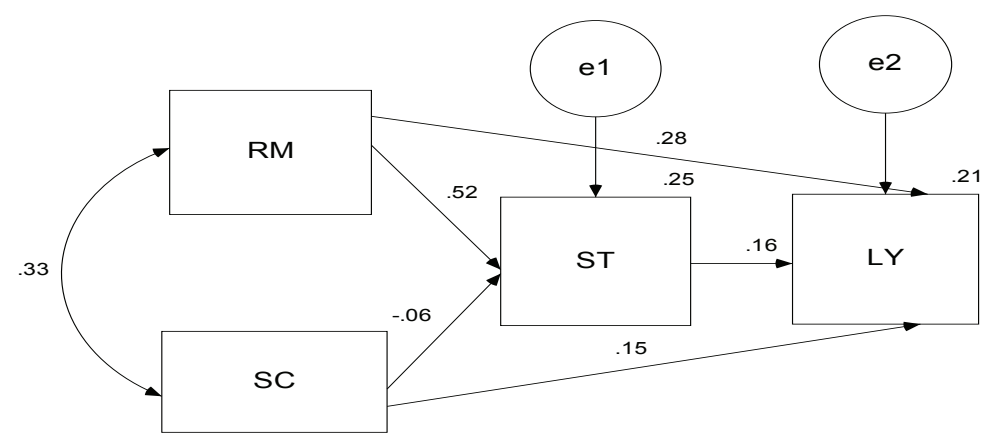

Figure 2.

Path Analysis Model 
Table 6.

Path Analysis Results

\begin{tabular}{cccccc}
\hline $\begin{array}{c}\text { Independent } \\
\text { Variable }\end{array}$ & $\begin{array}{c}\text { Dependent } \\
\text { Variable }\end{array}$ & $\begin{array}{c}\text { Standardized } \\
\text { Path } \\
\text { Coefficients }\end{array}$ & C $\boldsymbol{R}$ & Prob. & $\begin{array}{c}\text { Squared } \\
\text { Multiple } \\
\left.\text { Correlations (R }{ }^{2}\right)\end{array}$ \\
\hline RM & ST & 0.519 & 7.690 & 0.000 & \\
SC & & -0.056 & -0.832 & 0.405 & 0.253 \\
RM & & 0.280 & 3.509 & 0.000 & \\
SC & LY & 0.155 & 2.224 & 0.026 & \\
ST & & 0.164 & 2.165 & 0.030 & 0.210 \\
\hline
\end{tabular}

All hypotheses examined are accepted; all of them are significant except $\mathrm{H}_{2} \cdot \mathrm{H}_{1}$ examined the direct positive effect of relationship marketing (RM) on customers' satisfaction (ST). Relationship marketing had a significant positive effect on customers' satisfaction $(\beta=.519, \mathrm{CR}=7.690)$ was supported. While $\mathrm{H}_{2}$ examined the direct positive effect of shariah compliance (SC) on customers' satisfaction (ST) was not supported $(\beta=.056, \mathrm{CR}=0.832) . \mathrm{H}_{3}$ examined the direct positive effect of relationship marketing (RM) on customers' loyalty (LY). Relationship marketing has a significant effect on customers' loyalty $(\beta=.280, \mathrm{CR}=3.509)$ was supported. $\mathrm{H}_{4}$ explicated the direct positive effect of shariah compliance (SC) on customers' loyalty (LY) was also supported $(\beta=.155, \mathrm{CR}=2.224)$. Lastly, $\mathrm{H}_{5}$ explicated the direct positive effect of customers' satisfaction (ST) on customers' loyalty (LY) was also supported $(\beta=.164, \mathrm{CR}=2.165)$.

In sum, the constructs of relationship marketing (RM) and shariah compliance (SC) have a significant direct positive effect on customers' loyalty $\left(\mathrm{H}_{3}, \mathrm{H}_{4}\right)$. The most significant impact on customers' loyalty is relationship marketing, while shariah compliance had relatively less impact on customers' loyalty. Summary of hypotheses test results are shown in table 7. 


\section{Table 7. \\ Summary of Hypotheses Test Results}

\begin{tabular}{lll}
\hline Items & \multicolumn{1}{c}{ Hypotheses } & Findings \\
\hline $\mathrm{H}_{1}$ & $\begin{array}{l}\text { Relationship marketing had a direct positive } \\
\text { effect on customers' satisfaction }\end{array}$ & Supported \\
$\mathrm{H}_{2}$ & $\begin{array}{l}\text { Shariah compliance had a direct positive } \\
\text { effect on customers' satisfaction }\end{array}$ & Not Supported \\
$\mathrm{H}_{3}$ & $\begin{array}{l}\text { Relationship marketing had a direct positive } \\
\text { effect on customers' loyalty }\end{array}$ & Supported \\
$\mathrm{H}_{4}$ & $\begin{array}{l}\text { Shariah compliance had a direct positive } \\
\text { effect on customers' loyalty }\end{array}$ & Supported \\
$\mathrm{H}_{5}$ & $\begin{array}{l}\text { Customers' satisfaction had a direct positive } \\
\text { effect on customers' loyalty }\end{array}$ & Supported \\
\hline
\end{tabular}

This research examined the effect of relationship marketing and shariah compliance on customers' satisfaction and customers' loyalty. The results of the research suggest that relationship marketing and shariah compliance had positive direct effects on customers' loyalty. However, the positive effect of shariah compliance on customers' satisfaction was not supported.

As hypothesized, relationship marketing had a direct positive effect on customers' loyalty. This result supports the previous findings (Alrubaiee and Al-Nazer, 2010: 156; Ndubisi, 2007: 98; Taleghani, et.al, 2011: 155; Prabowo, 2008: 92; Sucahyo, et.al, 2013: 151; Semuel, 2012: 33) which demonstrated the direct positive effect of relationship marketing on customers' loyalty. The results suggest that relationship marketing plays an important role on customers' loyalty in Islamic microfinance. Similar to the previous findings (Mulindwa, 2005: 12; Gyasi, 2012: 1; Prabowo, 2008: 92; Sucahyo, et.al, 2013: 151), relationship marketing had strong effect on customers' satisfaction. Relationship marketing had a direct positive effect on customers' satisfaction. This result is consistent with the previous findings (Mulindwa, 2005: 12; Gyasi, 2012: 1; Prabowo, 
2008: 92; Sucahyo, et.al, 2013: 151). However, the relationship of shariah compliance with customers' satisfaction was not significant. Thus, the leader of Islamic microfinance should focus on keeping customers' satisfaction through shariah compliance. Customers' satisfaction had a direct positive effect on customers' loyalty. This result is consistent with the previous findings (Alrubaiee and AlNazer, 2010: 156; Prabowo, 2008: 92; Sucahyo, et.al, 2013: 151). These findings emphasize the importance of measuring relationship marketing and shariah compliance on customers' loyalty.

\section{Conclusion}

The main objective of this research was to investigate the effect of relationship marketing and shariah compliance on customers' satisfaction and customers' loyalty. The finding of this research had some important contributions. First, relationship marketing had significant contribution on customers' satisfaction, especially its impact on customers' loyalty. Therefore, the most significant effect on customers' satisfaction was relationship marketing. Second, this research supports that shariah compliance had no effect on customers' satisfaction. However, in this research, it was found that shariah compliance was indirectly able to influence the customers' loyalty through customers' satisfaction. This inconsistency suggests that the shariah compliance in the Islamic microfinance can be evaluated in the future study.

The present research suggests that Islamic microfinance should focus more on satisfying their customers, as it influences the customers' loyalty. Especially, nowadays, in context of high competitive and globalize Islamic banking in finance, increasing customers' loyalty is emerged as the most important challenges faced by marketers. Cultivating customers' loyalty is frequently argued to be the most important driver of organizations in long-term financial performance, which can lead to increased sales and customer share, lower costs, and higher prices.

Lastly, the research findings must be considered within the limitations of research methodology. This research focuses only on 
the Islamic microfinance. Additional research is needed to examine these relationships within and across additional sector. This research is just conducted in one region. The researcher expects to the other researchers to have study in other regions. Another limitation is from the use of variable. Relationships investigated in the present research deserve further research, especially by adding some other variables, like customer value and product innovation.

\section{References}

Alrubaiee, Laith., and Al-Nazer, Nahla. 2010. "Investigate the Impact of Relationship Marketing Orientation on Customers' loyalty: The Customer's Perspective". International Journal of Marketing Studies, Vol. 2, No. 1: 155-174.

El-Refae, Basheer Abbas al-Alak Ghaleb Awad. 2012. "The Relationship between Service Quality, Satisfaction and Behavioral Intentions of Malaysian Spa Center Customers", International Journal of Business and Social Science, Vol. 3, No. 1: 198-205.

Ghozali, Imam. 2008. Model Persamaan Struktural Konsep dan Aplikasi dengan Progran AMOS 16.00, Semarang: UNDIP.

Gronroos, Christian. 1994. "From Marketing Mix to Relationship Marketing: towards a Paradigm Shift in Marketing". Management Decision, Vol. 32, No. 2: 4-20.

Gyasi, Beauty Esi. 2012. "Customer Relationship Marketing and Customer Retention: The Perspectives of Customer of Access Bank Ghana Limited". Thesis, Commonwealth Executive Master of Business Administration.

Hanzaee, Kambiz Heidarzadeh and Khanzadeh, Mahmoud. 2011. "Investigation of the Effect of Consumption Emotions on Satisfaction and Word of Mouth Communications", MiddleEast Journal of Scientific Research, Vol. 9, No. 5: 566-571. 
Morgan, Robert M., and Hunt, Shelby D. 1994. "The CommitmentTrust Theory of Relationship Marketing". Journal Marketing, Vol. 58, No. 3: 20-38.

Mulindwa, Charles. 2005. "Relationship Marketing and Customer Retention in the Printing Equipment Industry: A Case Study of Heidelberg East Africa Ltd", Dissertation, Master of Business Administration of Mukerere University.

Ndubisi, N.O. 2007. "Relationship Marketing and Customers' loyalty". Marketing Intelligence and Planning, Vol. 25, No. 1: 98-106.

Oliver, R. 1997. Satisfaction as Behavioral Perspective on the Customer, New York: McGraw-Hill.

Olotu, Ayopo O., Maclayton, Darego W., and Opara, Bright C. 2010. "An Empirical Study of Relationship Marketing Orientation and Bank Performance". Research Journal of International Studies, Vol. 16: 47-57.

Othman, Abdul Qawi., and Owen, Lynn. 2001. "The Multi Dimensionality of CARTER Model to Measure Customer Service Quality (SQ) in Islamic Banking Industry: A Study in Kuwait Finance House". International Journal of Islamic Financial Services, Vol. 3, No. 4: 1-12.

Palmatier, Robert, W. 2008. Relationship Marketing, Cambridge: Marketing Science Institute.

Prabowo, Budi. 2008. "Pengaruh Relationship Marketing terhadap Loyalitas Pelanggan melalui Kepuasan elanggan pada PT. Astra Surabaya”. Jurnal Ilmu-Ilmu Sosial, Vol. 8, No. 2: 92-97.

Ravald, Annika and Gronroos, Christian. 1996. "The Value Concept and Relationship Marketing". European Journal of Marketing, Vol. 30, No. 22: 19-30.

Rizan, Mohamad; Warokka, Ari and Listyawati, Dewi. 2014. "Relationship Marketing and Customers' loyalty: Do 
Customers' satisfaction and Customer Trust Really Serve as Intervening Variables? ", Journal of Marketing Research and Case Studies, Vol. 2014, 1-12.

Rokhman, Wahibur. 2013. "The Effect of Islamic Microfinance on Poverty Alleviation: Study in Indonesia”. Economic ReviewJournal of Economics and Business, Vol. XI, No. 2: 1-15.

Semuel, Hatane. 2012. "Customer Relationship Marketing Pengaruhnya terhadap Kepercayaan dan Loyalitas Perbankan Nasional”. Jurnal Manajemen Pemasaran, Vol 7, No. 1: 33-41.

Sheth, Jagdish N., and Parvatiyar, Atul. 1995. "The Evolution of Relationship Marketing”. International Business Review, Vol. 4, No.4: 397-418.

Sin, Leo YM., Tse, Alan CB., Yau, Oliver HM., Chow, Raymond PM., Lee, Jenny SY., \& Lau, Lorett BY. 2005. "Relationship Marketing Orientation: Scale Development and Cross-Cultural Validation". Journal of Business Research, Vol. 58: 185-194.

Sucahyo, Afan Doni., Fauzi, Achmad DH., and Arifin, Zainul. 2013. "Analisis Pengaruh Customer Relationship Marketing Pemasaran Hubungan Pelanggan dalam Meningkatkan Kepuasan dan Loyalitas (Survei pada Nasabah Bank Tabungan Pensiunan Nasional Mitra Usaha Rakyat Kantor Cabang Bojonegoro". Jurnal Profit, Vol. 7, No. 1: 151-156.

Taleghani, Mohammad., Gilaninia, Shahram., and Mousavian, Seyyed Javad. 2011. "The Role of Relationship Marketing in Customer Orientation Process in the Banking Industry with Focus on Loyalty (Case Study: Banking Industry of Iran". International Journal of Business and Social Science, Vol. 2, No. 19: 155-166. 
Tuan, Nguyen Minh. 2012. "Effects of Service Quality and Price Fairness on Student Satisfaction", International Journal of Business and Social Science, Vol 3, No. 19: 132-150. 